\section{Total tannin levels analysis of brown algae (sargassum sp. and padina sp.) to prevent blood loss in surgery}

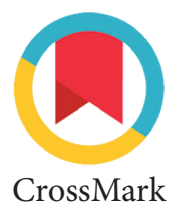

\author{
Abul Fauzi*, Satriani Lamma, Muhammad Ruslin
}

\title{
Abstract
}

Objective: Tooth extraction in oral surgery may cause complications such as bleeding. A ttannin is an astringent group that can accelerate the process of bleeding cessation by precipitating the blood protein, specifically thrombin. One of the plants containing tannin is brown algae. The total tannin level in brown algae, specifically sargassum sp. and padina sp., will be determined.

Material and Methods: This research is an experimental research using post-test only with control group design. The seaweed used in this study was taken from the waters of Punaga, Takalar. The dried seaweed was subsequently extracted using maceration. Extracts were diluted using ethanol and. then was reacted with 7.5\% Folin and $1 \% \mathrm{NaOH}$. The measurement of tannin level was performed using a standard curve of tannic acid.

Results: Total tannin level of sargassum sp. was $0.5152 \pm 0.9634 \%$, while the total tannin level of padina sp. was $1.1321 \pm 0.09747 \%$.

Conclussion: Padina sp. has a higher total tannin level than sargassum sp.
Department of Oral and Maxillofacial Surgery, Faculty of Dentistry, Hasanuddin University, Makassar, Indonesia
*Corresponding to: Department of Oral and Maxillofacial Surgery, Faculty of Dentistry, Hasanuddin University, Makassar, Indonesia abulfauzi@unhas.ac.id

Received: 5 November 2017 Revised: 30 January 2018 Accepted: 18 February 2018 Available online: 1 April 2018

Keywords: Brown algae, Sargassum sp., Padina sp., Total tannin, Anti-hemorrhagic

Cite this Article: Fauzi A, Lamma S. 2018. Total tannin levels analysis of brown algae (Sargassum sp. and Padina sp.) to prevent blood loss in surgery. Journal of Dentomaxillofacial Science 3(1): 37-40. D0I: 10.15562/jdmfs.v3i1.621

\section{Introduction}

A wound is caused by damage to normal skin anatomical structures and functions due to pathological processes originating from both internal and external and hit particular organs. A wound can be chronic or acute. Acute wounds occur in a rapid process and the healing is predictable. Unlike the acute wound, chronic wounds healing time is unpredictable and can be said to be healed if the function and structure of the skin are back intact. Some wounds are accompanied by complications of bleeding. Under normal circumstances, bleeding will be accompanied by a process known as hemostasis which is a spontaneous response of the body to prevent excessive blood loss. ${ }^{1}$ Some methods have been developed to assist wound healing. Wound healing methods consist of components that act as stimulants and can aid the wound through several stages of hemostasis, inflammation, proliferation, and remodeling. ${ }^{2}$ In research by Galang et al. ${ }^{3}$ biochemical compounds, such as tannins and flavonoids, have anti-bleeding effects that accelerate the formation of blood clots.

A tannin is an astringent that can precipitate blood proteins such as thrombin. Thrombin converts fibrinogen into a set of fibrin fibres in the wound to stop bleeding. ${ }^{3}$ In addition to healing wounds and stopping bleeding, tannins can also stop the infection internally. Tannins have the ability to form a layer of protection on injured tissues keeping the wound from becoming more infected. Tannins are also useful when applied to the oral mucosa and are effective in keeping the kidneys healthy. ${ }^{4,5}$

Tannins are abundantly available in almost all plant species including brown algae. Beaches with abundant chocolate algae in South Sulawesi can be found in the Takalar District, namely Punaga Beach and Puntondo. The local community cultivates brown algae for their livelihood and therefore, brown algae can be found easily in the coastal areas of Punaga Beach and Puntondo.

Based on the description above, the researchers are interested in proving the presence of tannins and total tannins in brown algae, namely Sargassum sp. and Padina sp., The researchers are also intersting in observing which brown algae is more effective for anti-bleeding.

\section{Material and Methods}

This research is an experimental research design post-test only with control group design. Sampling was conducted in Punaga waters, Takalar District, South Sulawesi. Further research was conducted at the Laboratory of Biopharmaca Faculty of Pharmacy, Hasanuddin University.

Brown algae were cleaned with running water and then dried to get dry samples, or simplicia, of both algae. A total of 250 grams of simplicia from 
both brown algae was then dissolved using ethanol to be processed using maceration. Macerated simplicia were then put into an evaporator until a thickened extract was obtained.

The extracts obtained from both types of brown algae were then prepared into three different concentrations of $150 \mathrm{ppm}, 300 \mathrm{ppm}$ and $450 \mathrm{ppm}$. Each concentration was prepared in triplicate. Each sample was then reacted with folin $7.5 \%$ and $1 \%$ sodium hydroxide $(\mathrm{NaOH})$ before measuring the tannin content by comparing to a standard curve of tannic acid.

\section{Results}

Table 1 shows the measurement of the total tannin level in Sargassum sp. samples. Figure 1 shows that $150 \mathrm{ppm}$ of Sargassum sp. contains $0.464 \pm 0.136 \%$ of tannins, where as $300 \mathrm{ppm}$ contains $0.498 \pm$ $0.035 \%$ and $450 \mathrm{ppm}$ contains $0.584 \pm 0.077 \%$.

Table 2 shows the total tannin levels in Padina sp. samples. Figure 2 shows that $150 \mathrm{ppm}$ of Padina sp. contains $1.109 \pm 0.090 \%$ of tannins, where as $300 \mathrm{ppm}$ contains $1.072 \pm 0.019 \%$ and $450 \mathrm{ppm}$ contains $1.216 \pm 0.113 \%$.

Table 1 Total tannin levels in samples of Sargassum sp.

\begin{tabular}{lccc}
\hline Concentration & Replication & Total Tannin Levels & Avg. \pm SD \\
\hline \multirow{2}{*}{$150 \mathrm{ppm}$} & I & 0.523 & \\
& II & 0.559 & $0.464 \pm 0.136$ \\
$300 \mathrm{ppm}$ & III & 0.308 & \\
& I & 0.459 & $0.490 \pm 0.035$ \\
$450 \mathrm{ppm}$ & II & 0.513 & \\
& III & 0.523 & $0.580 \pm 0.077$ \\
& I & 0.495 & \\
\hline
\end{tabular}

Table 2 Total tannin levels in samples of Padina sp.

\begin{tabular}{lccc}
\hline Concentration & Replication & Total Tannin Levels & Avg. \pm SD \\
\hline $150 \mathrm{ppm}$ & I & 1.025 & \\
& II & 1.204 & $1.109 \pm 0.090$ \\
$300 \mathrm{ppm}$ & III & 1.097 & \\
& I & 1.061 & $1.072 \pm 0.019$ \\
$450 \mathrm{ppm}$ & II & 1.093 & \\
& III & 1.061 & $1.216 \pm 0.113$ \\
& I & 1.166 & \\
\hline
\end{tabular}

Table 3 The average total tannin levels based on sample types (Sargassum sp. and Padina sp.)

\begin{tabular}{llc}
\hline \multicolumn{1}{c}{ Sample } & & Tannin \\
\hline \multirow{2}{*}{ Sargassum sp. } & Mean & 0.5152 \\
& $\mathrm{~N}$ & 9 \\
Padina sp. & Std. Deviation & 0.09634 \\
& Mean & 1.1321 \\
& $\mathrm{~N}$ & 9 \\
Total & Std. Deviation & 0.09747 \\
& Mean & 1.8237 \\
& $\mathrm{~N}$ & 18 \\
& Std. Deviation & 0.33102 \\
\hline
\end{tabular}

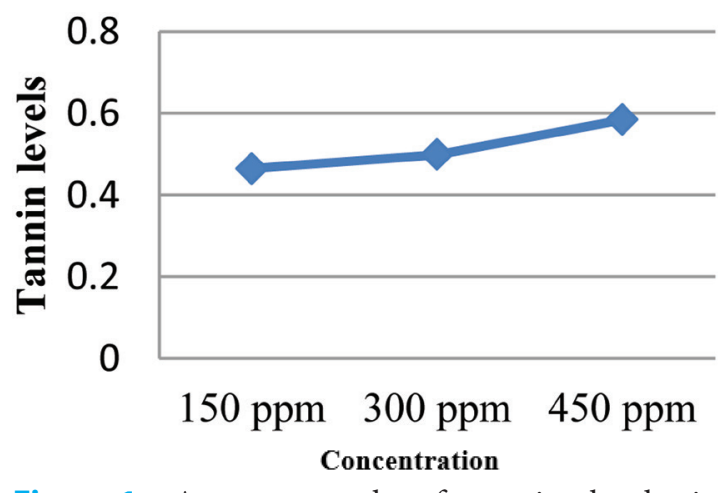

Figure 1 Average graph of tannin levels in Sargassum sp.

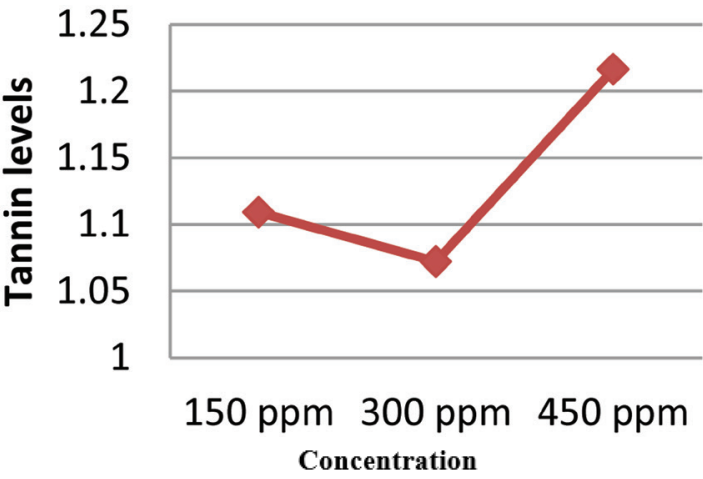

Figure 2 Graph of average total tannin levels in Padina sp.

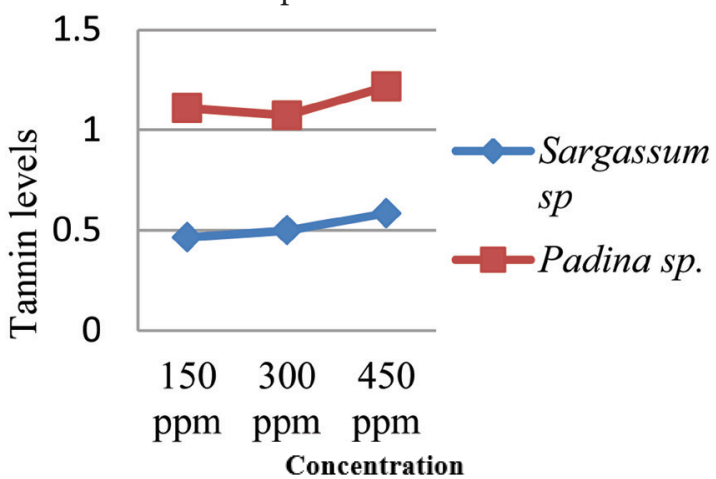

Figure 3 Comparison of total tannin levels in both samples (Sargassum sp. and Padina sp.) 
In table 3 it can be seen that the total tannin levels in Sargassum sp. is $0.5152 \pm 0.09634 \%$, while the total tannin levels in Padina sp. is $1.1321 \pm$ $0.09747 \%$. Therefore, Padina sp. has a greater value than Sargassum sp, shown in figure 3.

\section{Discussion}

Bleeding is a process of blood escaping from blood vessels due to damage to blood vessel walls caused by trauma or disease. ${ }^{6}$ Bleeding occurs due to tearing of the capillaries or blood vessels which are required in the healing process. If the bleeding is excessive, it is necessary to consider whether it is a complication. ${ }^{7,8}$ Excessive bleeding results from the failure of a hemostatic process that can cause clinical problems. Bleeding can be caused by a deficiency of a blood clotting factor. ${ }^{9}$

Hemostasis is a body defence mechanism that plays an important role to stop bleeding. The process of hemostasis is divided into four main stages, vasocontriction, platelet aggregation, platelet adhesion and blood coagulation. Vasoconstriction is a preliminary response to injury through the shrinking of smooth muscle cells within the walls of blood vessels that serves to reduce blood flow through damaged blood vessels. Platelet aggregation occurs after the injured blood vessels undergo vasoconstriction. Platelets aggregate to form platelet plugs which will be further strengthened by fibrin formed through blood clotting process. The injured blood vessels will cause damage to endothelial cells and open the connective tissue underneath. This leads to platelet adhesion, which is the process of platelet attachment on foreign surfaces, especially collagen fibre. Platelets will also be attached to other platelets called platelet aggregation. ${ }^{10}$

A tannin is an astringent extracted from plant polyphenols that can bind, precipitate or the mechanism of tannins as vasoconstrictors is through its astringent effects. Tannins accelerate the release of proteins from cells and precipitates these proteins on the cell surface. They also reduce capillary secretion and permeability, intercellular space contraction, hardening the capillary endothelium and form a protective layer of skin that makes the superficial cell layer tighten and shrink. This will result in local vasoconstriction of the capillaries. ${ }^{11}$

Tannins can also precipitate blood proteins such as albumin. This protein precipitation process will induce $\mathrm{A}_{2}$ thromboxane synthesis to increase platelet aggregation, thereby accelerating the formation of temporary platelet blockages in injured blood vessels.

In addition to healing wounds and stopping bleeding, tannins can also stop the infection internally. The ability of tannins to form a layer of protection on injured tissue keeps the wound from becoming more infeected. Tannins are also useful when applied to the oral mucosa. ${ }^{4}$

As pharmacological agents in the field of dentistry, tannins act as astringents and gingival regeneration agents. Tannins as an astringent causes local coagulation in the superficial regions. One of the astringent products containing tannins is Clonera which can be used for bleeding gums. Clonera is available in various preparations such as a gel and a mouthwash. Gingival regeneration agent (gum paint) is a combination of antiseptic and tannin agents that have antibacterial, anaesthetic and gingival regeneration effects. One of the gum paint products is Stolin gum paint. ${ }^{12}$

In this research, the total tannin level was measured by colourimetric method using Folin Ciocalteu reagent and then measured by spectrophotometer.

The extraction method used was maceration. Maceration is the process of extracting simplicia using solvent at room temperature. The principle of maceration is the diffusion of solvent fluid into plant cells containing active compounds. The maceration method is chosen because it has advantages. It is simple, because it does not require complicated equipment, it avoids damage to compounds that are not heat resistant, and it is relatively cheap ${ }^{13}$ The solvent used was $70 \%$ ethanol because this solvent can extract the tannin compounds optimally. ${ }^{14}$ In addition to having a wide range of polarizing abilities ranging from polar and nonpolar compounds, ethanol is not like other organic solvents that have a higher toxicity potential. ${ }^{15}$

The determination of total tannin level in both samples was done using Folin Ciocalteu and standard tannic acid. Folin Ciocalteu reagent was used because the tannin substance can react with Folin to form a blue solution that can be measured for absorbance. ${ }^{16}$

The choice of tannic acid as the standard curve was because the tannic acid is in the hydrolyzed tannin class and can be used as a comparison in the measurement of total tannin levels. ${ }^{17}$ The optimal maximum wavelength of $724.5 \mathrm{~nm}$ was detemined from the standard curve of tannic acid. The sample solution was then measured using a spectrophotometer at $724.5 \mathrm{~nm}$ according to the maximum wavelength obtained from the standard curve.

During the reaction between the tannin and Folin Ciocalteu, the hydroxyl group on the tannin substance reacts with the Folin Ciocalteu reagentto form a blue moblidenum-tungsten complex. The blue colour will be more concentrated as more phenolic ions are formed. This means that greater concentrations of tannins results in more 
concentrated blue colour and an increase in the absorbance value. $^{18}$

This is consistent with the colour ratio of the sample solution after it has been reacted with Folin Ciocalteu. Sample solution of Padina sp. is a solid blue while the sample solution of Sargassum sp. is a clear blue. This means the concentration of phenolic ions from tannins in Padina sp. is higher than in Sargassum sp.

This shows that the tannin levels of Sargassum sp. and Padina sp. are lower than the two anti-bleeding drug products. The tannins found in plants could be used to treat internal oral diseases, this includes brown algae that has been tested to contain tannins. ${ }^{19}$

Research conducted by Tirtawijaya ${ }^{20}$ showed that there is an ability of tannins in protein clumping. Tannins that react with proteins will form water-insoluble copolymers that can cause shrinkage of skin pores, hardening of the skin, stop diffusion and light bleeding. Thus, can cover the wound and prevent common bleeding in the wound.

\section{Conclusion}

Based on the results obtained from the measurement of the total tannin levels in the extract of Sargassum sp. and Padina sp., it can be deduced that Padina sp. has a higher total tannin level than Sargassum sp. Padina sp. is considered to have more effective anti-bleeding activity than Sargassum sp. in terms of the total tannin concentration. In conclusion, both Padina sp. and Sargassum sp. have a lower tannin level than oral mucosal anti-bleeding drugs such as clenora and stolin gum paint.

\section{Acknowledgement}

The authors state no funding to declare.

\section{Conflict of Interest}

The authors report no conflict of interest.

\section{References}

1. Meidina S, Rosina T. Penggunaan bahan pada perawatan luka di RSUD Dr. Djasamen Saragih Pamatang siantar. Jurnal keperawatan klinis 2012;2: 1-2.

2. Oky M, Menkher M, Andani EP, et al. Pengaruh cairan Culture Filtrate Fibroblast (CFF) terhadap penyembuhan luka; penelitian eksperimental pada Rattus novergicus Gallur Wistar. Jurnal kesehatan Andalas 2012;1: 112-113.
3. Galang RPH, Ika A. Pengaruh pemberian ekstrak etanol daun kelor (Moringa oleifera) terhadap waktu perdarahan gingivitis pada tikus Sprague-Dawley. Jurnal UMY 2015;1: 2-3.

4. Regina T. Ekstrak etil asetat dan etanol daun sirih (Piper betle $\mathrm{L}$.) dapat memperpendek waktu perdarahan mencit (mus musculus). J kesehatan gigi 2013;1: 33.

5. Asmawati A, Hasyim R, Lianingsih A, Ariani D. The difference of anti-inflammatory effect of brown algae extract panida sp. and sargassum sp that is derived from Punaga beach, South Sulawesi. J Dentomaxillofac Sci 2016;1: 116-119.

6. Jane W, Bernat H, Wellsy L. Pengaruh pemberian ekstrak biji pinang (Areca cathecu) terhadap waktu perdarahan pasca ekstraksi gigi pada tikus jantan Wistar (Rattus norvegicus I). Jurnal Ilmiah Sains 2015;15: 129-134.

7. Liliani SL, Winny A, Zainul C. Perpanjangan waktu perdarahan pada pemberian perasan bawang merah (Allium ascalonicum). E-jurnal pustaka kesehatan 2014;2: 542-546.

8. Anjar MK, Adri N, Susanti, et al. Aktivitas penghentian pendarahan luar ekstrak etanol daun berenuk secara In-Vivo. Jurnal farmasi UMP 2016;1: 1-6.

9. Tita N, Constantia, Dwei N, et al. Aktivitas hemostatik ekstrak etanol daun andong (cordyline fructicosa [L.] A. Cheval) terhadap mencit jantan Galur Swiss-Webster. Jurnal kesehatan bakti tunas husada. 2016;16: 118-125.

10. Sabiston. Buku Ajar Bedah, bagian 1. Jakarta: penerbit buku kedokteran EGC; 1995. 98, 108.

11. Fransisca B, Nursid M, Bambang C. Analisis kuantitatif B-karoten dan uji aktivitas karotenogen dalam alga coklat Turbinaria decurrens. J sains dan matematika 2009:17: 90-92.

12. Mohan M, Gupta A, Shenoy V, et al. Pharmacological agents in dentistry: a review. British J of Pharma Research 2011;1: 80-83.

13. Untari EK, Wahdaningsih S, Damayanti A. Efek fraksi n-heksana kulit Hylocereus polyrhizus terhadap aktivitas katalase tikus stres oksidatif. Pharm Sci Res 2014;1: 145.

14. Aisyah TS, Ari A. Kajian sifat fitokimia ekstrak rumput laut coklat sargassum Duplicatum menggunakan berbagai pelarut dan metode ekstraksi. Jurnal Agrointek 2012;6: 22-27.

15. Wahyu, Mushollaeni, Endang, et al. Karakterisasi natrium alginat dari sargassum sp., turbinaria sp. dan padina sp. (characterization of sodium alginate from sargassum sp., turbinaria sp. and padina sp.) J Teknologi dan Indutri Pangan 2011;22: 26-32.

16. Andi H, Malik Abd, Ahmad N. Penetapan kadar fenolik total dari ekstrak etanol bunga rosella (Hibiscus sabdariffa L.) berwarna ungu menggunakan spektrofotometri UV-VIS. J Fitofarmaka Indonesia 2011;3: 119-123.

17. Supriyanto R. Studi analisis spesiasi ion logam Cr(III) dan Cr(IV) dengan asam tanat dari ekstrak gambir menggunakan spektrofotometri UV-Vis. J sains MIPA 2011;17: 36.

18. Pranoto EN, Ma’ruf WF, Pringgenies D. Kajian aktivitas bioaktif ekstrak teripang pasir (Holothuria scabra) terhadap jamur. J pengolahan dan Biotek Hasil perikanan 2012;1: 4 .

19. Jamal R.Q. Prospects of wild medicinal and industrial of plants of saline habitats in Jordan valley. Pak Journal Bot 2015;47: 554

20. Tirtawijaya D. Penentuan jenis tanin secara kualitatif dan penetapan kadar tanin dari kulit buah rambutan (nephelium lappaceum L.) secara permanganometri. Jurnal ilmiah mahasiswa Universitas Surabaya 2015;4: 2.

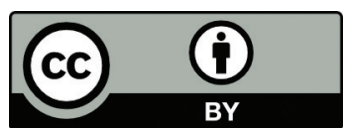

This work is licensed under a Creative Commons Attribution 